\title{
Endophytic fungi of three economic plant roots in Sohag, Upper Egypt
}

\author{
O.M.O. El-Maghraby, S.M. Soltan, Rehab M. Mohammed, Maha M. Mohammed \\ Botany Department, Faculty of Science, Sohag University, Sohag, Egypt.
}

Rec. 28 May, 2014, Accept. 29 June, 2014

\begin{abstract}
Ninety species in addition to three species varieties belonging to thirty-one genera were isolated and identified from three economic plant roots (Saccharum officinarum, Corchorus olitorius and Triticum aestivum) on PDA and water agar at $28 \pm 2^{\circ} \mathrm{C}$. Fusarium (15 species, 45/60 samples and 31.4\% of total fungi) and Aspergillus $(15+2,34 / 60$ and 17\%) were the dominant genera on PDA, whereas, Fusarium (13 species, 38/60 samples and 33.8\% of total fungi) and Drechslera (6, 28 and 13.1\%) were the commonest on water agar media. Of the previous genera $F$. udum, $F$. anthophilum, $F$. subglutinans, A. terreus var. aureus, A. flavus, D. biseptata and D. bicolor were the most detected species on PDA and WA. The endophytic fungi isolated belonging to anamorphic fungi (57 species, 23 genera of 11 order), Ascomycotina (26, 4 of 1) and Zygomycota (1, 1 of 1$)$ on PDA and $(38,15$ of 8$) \&(11,2$ of 1) belonging to anamorphic fungi and Ascomycotina on WA, while Zygomycota disappeared on WA.
\end{abstract}

Key words: Endophytes, sugarcane, jute, wheat, roots.

\section{Introduction}

Fungal endophytes are micro fungi that colonize living tissues of plants without producing any apparent symptoms or obvious negative effects (Hirsch and Braun, 1992). The endophytic fungi represent an important and quantified component of fungal biodiversity, and are known to affect on plant community diversity and structure (Krings et al., 2007). Moreover, the fungal endophytes are known to play several roles such as providing protection against herbivorous insects, plant parasitic nematodes, plant pathogens, etc. (Vega et al., 2008).

Sugarcane (Saccharum officinarum L.) is the main source for sugar production and plays a vital economic role in many tropical countries as well as in Egypt (Jangpromma et al., 2010; Singh et al., 2010). Moreover, it is widely used in Egypt for fresh juice consumption and molasses industry. In addition to being a food crop, sugarcane is an efficient crop for producing fuel ethanol, biogas byproducts and fertilizers (Mahmood et al., 2007; Souza et al., 2010). Notably, the ascomycete Epicoccum nigrum has been frequently isolated as an endophyte of sugarcane plants (Stuart et al., 2010; Fávaro et al., 2011).

Jute (Corchorus olitorius L.) is an important green leafy vegetable in many tropical area including Egypt (Basu et al., 2004; Samra et al., 2007). The leaf extract of the plant is also employed in folklore medicine in the treatment of gonorrhea, pain, fever and tumor (Ndlovu and Afolayan, 2008). The crop is an excellent source of vitamin $\mathrm{A}$ and $\mathrm{C}$, fiber, minerals including calcium, and iron. It is reportedly consumed as healthy, vegetable in Japan because of its rich contents of carotenoids, vitamin $\mathrm{B} 1, \mathrm{~B} 2$, $\mathrm{C}$ and $\mathrm{E}$, and minerals (Ibrahim and Fagbohun, 2011). The production quality and yield of this economically important crop is affected by several biotic e.g. fungi, pest, insect, nematode, virus and mite (BBS, 2004; Keka et al., 2008).

Wheat (Triticum aestivum L.) is one of the important cereal crops of high nutritive value in the world as well as in Egypt. The total cultivated area by wheat in Egypt is about 3.2 million feddans during 2012/2013 season, produced about 8.5 million tons which not sufficient for national

\footnotetext{
* Corresponding author:

Dr. O.M.O. El-Maghraby

凶. Osmanelmaghraby@yahoo.com
} 
consumptions. Therefore, Egypt has to import about 8.5 million tons (FAO, 2013). The grains of wheat contain high amounts of proteins, carbohydrates in addition to some minerals and vitamins (Zaki et al., 2007; Bhoja et al., 2011). It is the most import staple food for about two billion people (36\% of the world population).

This work paves the way to further study the diversity of endophytic fungi isolated from roots of some economic plants for further investigations.

\section{Materials and Methods Collection of Plant Samples:}

Roots of three economical plants, sugarcane, jute and wheat (Poaceae and Tiliaceae) were collected from different locations in Sohag Governorate. The plants (each, 20 samples) were chosen to isolate of endophytic fungi. The collected plant materials were stored in separate plastic bags at $4^{\circ} \mathrm{C}$ in an ice box until isolation of endophytic fungi (Strobel and Daisy, 2003).

\section{Fungal Isolation and Identification:}

Isolation of endophytic fungi was done according to the method described by (Hallmann et al., 2007). The plant roots were rinsed gently in running water to remove adhered dust and debris. Samples were surface sterilized by ethyl alcohol (75\%) for $1 \mathrm{~min}$, soaked in sodium hypochlorite solution (5\%) for $3 \mathrm{~min}$, and then rinsed with ethyl alcohol $(75 \%)$ for $30 \mathrm{sec}$. They were finally rinsed with sterile distilled water and dried between two sterilized filter papers in laminar air flow chamber and the roots were cut into segments $(1 \mathrm{~cm})$.

Twenty sterilized segments of each root sample were placed on both PDA (potatoes "extract", 200.0 g; glucose, 20.0 g; agar, 15.0 $\mathrm{g}$; distilled water, to $1.0 \mathrm{~L}$ ) and WA media (agar, $15.0 \mathrm{~g}$; distilled water, $1.0 \mathrm{~L}$ ). The plates (4 plates, 5 segments for each) were incubated at $28^{\circ} \mathrm{C}$ for 15 days. The plates were periodically observed for fungal growth. The growing fungi were then subcultured on PDA and glucose-Czapek's agar media plates (glucose, $10.0 \mathrm{~g}$; NaNO3, 2.0 $\mathrm{g} ; \mathrm{KH}_{2} \mathrm{PO}{ }_{4}, 1.0 \mathrm{~g} ; \mathrm{MgSO}_{4} .7 \mathrm{H}_{2} \mathrm{O}, 0.5 \mathrm{~g} ; \mathrm{KC} 1$, $0.5 \mathrm{~g} ; \mathrm{FeSO}_{4} .7 \mathrm{H} 2 \mathrm{O}, 0.01 \mathrm{~g}$; agar, $15.0 \mathrm{~g}$; distilled water, $1.0 \mathrm{~L}$; $\mathrm{pH}, \quad 6.5-7)$ for purification and identification purposes. The endophytic fungal isolates were identified microscopically on the basis of their critical morphological structure such as hyphal features, arrangement of spores and reproductive structures (Raper and Fennell, 1965; Ellis, 1971; Pitt, 1979; Leslie and Summerell, 2006). Isolates that failed to produce reproductive structures after 3-4 weeks of incubation were referred to as sterile mycelia, and divided into their colour.

\section{Results and Discussion}

Endophytic fungi were isolated from roots of three economic plants. Most isolates were recorded in the first two weeks of incubation. These results correspond with other results obtained for the rate of isolation of endophytic fungi from other hosts (Shebany, 2008).

Ninety species and three species varieties which belong to thirty-one genera were isolated and identified based on anamorph and teleomorph from 60 samples of economic plant roots, sugarcane, jute and wheat (each, 20 samples) on both of PDA and WA media at $28 \pm 2^{\circ} \mathrm{C}$ (Tables, $1 \& 2$ ). While, seventy-eight species and six varieties belonging to twenty-one genera were isolated and identified from 60 samples of leguminous plant roots (peanut, alfalfa and broad bean) on both of PDA and WA media (El-Maghraby et al., 2013). The results in this study showed that most taxa isolated during this study belong to genera which have already been described as endophytes from different Egyptian hosts at different locations (Shebany, 2008; Nath et al., 2012).

The mycological studies in this investigation indicated that the endophytic fungi belonged to anamorphic fungi (57 species, 23 genera of 11 order), Ascomycotina (26, 4 of 1) and Zygomycota $(1,1$ of 1$)$ on PDA and $(38,15$ of 8$) \&(11,2$ of 1) belonging to anamorphic fungi and Ascomycotina on WA, while Zygomycota disappeared on WA (Table, 3).

The authors worked in this field reported that members of the Ascomycotina and Deutromycotina have been isolated as endophytes (Clay, 1991; Abd-Elaah and Soliman, 2005). Also, (Valachová et al., 2005). showed that most fungal endophytes belonged to Ascomycetes (Ascomycotina) and anamorphic fungi.

A total of 984 isolates from the three nonleguminous plant roots used were listed from sugarcane, jute and wheat $(314 \& 266,143 \&$ 
96 and $74 \& 91$ isolates on PDA and WA, respectively) as shown in tables $(1 \& 2)$. In this respect, a total of 597 isolates were isolated from the three leguminous plant roots (peanut, alfalfa and broad bean) on PDA and WA (229 \& 209, $230 \& 188$ and 138 \& 102 isolates, respectively) (ElMaghraby et al., 2013). The broad diversity of genera and species were isolated on PDA medium (20 genera \& 44 species +2 varieties; $14 \& 36+1$ and $14 \& 31+2$, respectively) compared with WA medium $(12 \& 22+1 ; 12 \& 20+1$ and $10 \& 21$, respectively) from sugarcane, jute and wheat, respectively. These results more acceptable with fungal genera and species isolated from leguminous plant roots (13 genera \& 41 species +3 varieties; $13 \& 36+2$ and $12 \&$ $32+1)$ on PDA compared with WA media $(12 \& 26+4 ; 9 \& 29$ and $8 \& 23+1)($ ElMaghraby et al., 2013). The differences in the number of isolates rely on the nature, age and other factors of the plants. Hoff et al. (2004). mentioned that endophytic fungi usually occur in above ground plant tissues but, are also found in root unlike mycorrhizal fungi, fungal endophytes of roots lack extra radical (outside the root) hyphal networks and mantles (sheaths around the roots).

Of the three economic plants studied, the most frequently occurring genus was Fusarium (21-36.6\% \& 27.5- 38.4\% of total fungi) and (60-100\% \& 40-95\% of the total samples) on both PDA and WA media, respectively. Followed by Aspergillus and Drechslera which were recorded with high frequency $(15-90 \%$ \& 10- $90 \%$ of the total samples) and low in the total fungal count (4.4- $21.3 \% \& 2.2-21.8 \%$ of total fungi on both PDA and WA media, respectively). Moreover, (El-Maghraby et al., 2013). reported that the most dominant genera isolated from three leguminous plant roots were Fusarium, Aspergillus and Penicillium. Most of genera were previously isolated as endophytic fungi by several researchers from different plants such as Fraxinus excelsior, Gossypium sp., Gynoxis oleifolia, Manilkara bidentata, Picea abies and Taxus sp. (Caruso et al., 2000; Wijeratne et al., 2006; Wang et al., 2007), twigs of Kandelia candel and Avicennia marina (Abdel-Wahab, 2000), different parts of Altheae rosea, Calotropis procera and Nerium oleander (Shebany,
2008) and roots, stems and leaves of Hyoscyamus muticus (Fatma et al., 2010).

Fusarium (16 species) was the most common genus regarding the number of cases of isolation and total fungal count from sugarcane, jute and wheat $(100,60 \& 65 \%$ of the samples and $36.6,21 \& 36.5 \%$ of total fungi, respectively) on PDA medium and $(95,55 \& 40 \%$ and $38.4,35.4 \& 27.5 \%$ of total fungi, respectively) on water agar medium (Tables, 1 \& 2). Also Fusarium (13 species) was the most common genus from peanut and alfalfa, each $95 \%$ of the samples and 28.4 and $44.35 \%$ of total fungi, respectively on PDA and $75 \& 80 \%$ of the samples and $22.5 \& 34.6 \%$ of total fungi, respectively on water agar medium (ElMaghraby et al., 2013). Fusarium spp. have been recorded as endophytes from Amomum siamense, Altheae rosea, Calotropis procera and Nerium oleander (Bussaban et al., 2001; Tian et al., 2004; Shebany, 2008). Of the species, F. udum, F. solani, F. anthophilum, $F$. subglutinans, and $F$. proliferatum were the dominant species recovered from the three economic plants $(5-65 \%$ of the samples, 3.3-40\% of total Fusarium and 0.7$13.7 \%$ of total fungi) on PDA and (5-50\%, $2.9-30.4 \%$ and $1-11.7 \%$ ) on WA media. These results more agree with results obtained by (El-Maghraby et al., 2013). where, $F$. solani, $F$. subglutinans, $F$. oxysporum, $F$. nygamai and $F$. anthophillum were the dominant species recovered from the three legumonous plants $(5-55 \%$ \& 5$45 \%$ of the samples, $1.5-49.23 \%$ \& $2-60 \%$ of total Fusarium and $0.32-14 \%$ \& $0.48-13.4 \%$ of total fungi on both PDA and WA media, respectively). In contrast, some of these species were recovered by (Shebany, 2008). with low counts from shoot system $(9.88 \&$ $10.29 \%$ of total Fusarium species and 1.75 \& $3.23 \%$ of total fungi) of Altheae rosea and Nerium oleander, respectively. On the other hand, $F$. solani was isolated from healthy leaves of Quercus ilex as endophytic fungi (Weber et al., 2007). and from healthy leaves of Manilkara bidentata (Lodge et al., 1996). $F$. oxysporum was isolated from roots of mangrove plants and also from branch of Theobroma cacao (Rubini et al. 2005).

Aspergillus was the second most prevalent genus based on the counts constituted $21.3,14.7 \& 15 \%$ of total fungi 
from sugarcane, jute and wheat, respectively on PDA and occupied the third place on WA $(4.5,19.8 \& 4.4 \%$ of total fungi) from the three previous plants. The genus was represented by 15 species in addition to 2 species varieties of which the most dominant species were $A$. terreus var. aureus and $A$. flavus (3/3 plants for each) and in counts $(14.9,10.4 ; 15.8,31.6 \& 18.2,18.2 \%$ of total Aspergillus and 3.2, 2.2; 2, $4.2 \& 2.7,2.7 \%$ of total fungi from sugarcane, jute and wheat, respectively) on PDA as shown in table (1). A. terreus var. aureus appeared only in 2 plants (sugarcane and jute) on WA (58.3 \& 5.3\% of total Aspergillus and $2.6 \&$ $1 \%$ of total fungi, respectively) (Table, 2). The genus was represented by 13 species in addition to 4 varieties of which, the most dominant species were $A$. tubingensis and $A$. terreus in three leguminous plant roots with low counts on PDA and WA media (ElMaghraby et al., 2013). The previous species were also recorded from lemon, sweet basilicum, mulberry and guava (Mohammed, 2010). A. tubingensis was isolated from sugarcane and wheat as the most dominant Aspergillus species (45 \& 5\% of the samples; $16.4 \& 9.1 \%$ of total Aspergillus and $3.5 \&$ $1.4 \%$ of total fungi, respectively) on PDA and $(15 \& 10 \% ; 33.3 \& 50 \%$ and $1.5 \&$ $2.2 \%$, respectively) on WA media. Moreover, A. tubingensis was the most dominant species isolated from three leguminous plant roots (peanut, alfalfa and broad bean) (18.2-24\% of total Aspergillus and $2.6-5 \%$ of total fungi on PDA) and (23.3-31.3\% and $2.7-4.9 \%$ on WA) (ElMaghraby et al., 2013). Also, A. tubingensis was isolated from mulberry, mille fleur and guava with rare frequency and low count (5\% of the samples for each, 7.7, $14.3 \&$ $4.5 \%$ of total Aspergillus and 3.23, 5 \& $3.33 \%$ of total fungi, respectively) (Mohammed, 2010).

Also, Drechslera was isolated from sugarcane, jute and wheat with moderate or low counts which collectively comprised 2.2 $\& 21.8,9.8 \& 3.1$ and $13.5 \& 14.3 \%$ of total fungi and high, moderate or low frequency $20 \& 90,40 \& 10$ and $25 \& 40 \%$ of the samples on PDA \& WA, respectively. These results were in agreement with results obtained by (Shebany, 2008 and Mohammed, 2010). that isolated Drechslera spp. from root and leaves of some medicinal plants. Also, (El-Maghraby et al., 2013). isolated Drechslera with rare in counts (3$1.5 \% \& 1.4-9 \%$ of total fungi) and moderate or less in frequency $(10-20 \% \& 5-40 \%$ of the samples) on PDA and WA media, respectively from three leguminous plant roots. $D$. biseptata and $D$. bicolor were the most detected species (1.4- $12.8 \%$ \& $1.1-7.14 \%$ of total fungi and $10-65 \%$ \& $5-35 \%$ of the samples, respectively) on the two isolation media. These species were recovered as endophytic fungi from many plants around the world (Rubini et al., 2005; Ganley and Newcombe, 2006; Weber et al., 2007).

Five genera namely, Penicillium (7 species), Cylindrocarpon (2 species +1 variety), Curvularia (6 species), Humicola (2 species) and Alternaria (3 species) were recorded in all plants tested with low or moderate count $(0.32-17.5 \%$ of total fungi) and frequency (5-30\% of the samples). Also, two genera were observed in two plants with low in counts (0.96-7\%) and rare or low frequency (5-20\%) and these were Paecilomyces (2 species) and Macrophomina (1 species) on PDA only as shown in table (1). On the other hand, Penicillium, Cylindrocarpon and Curvularia were also recorded in all plants tested with less in counts (0.38- $13.5 \%$ of total fungi) and frequency (5-30\% of the samples) on WA, table (2). While, Alternaria was observed in two plants with less in counts $(1.1-1.5 \%$ of total fungi) and frequency (5-10\% of the samples) and Humicola in only one plant with rare in counts (2.1\% of total fungi) and frequency (10\% of the samples) on WA medium (Table, 2). These species were recovered as endophytic fungi from many plants (Rubini et al., 2005; Ganley and Newcombe, 2006; Weber et al., 2007). Penicillium spp. have been commonly recorded as endophytes from leaves and roots of various hosts such as soybean leaves (Larran et al., 2002). and roots of Alnus glutinosa (Cappellano et al., 1987; Fisher et al., 1991; Caruso et al., 2000). isolated Alternaria from woody tissues and herbaceous tissues of Taxus sp. In particular, Alternaria was isolated from all the analysed plant materials and can be considered a resident genus of Taxus tissues. Moreover, Cylindrocarpon was isolated from roots of healthy potato plant (Götz et al., 2006).

Sterile mycelia were observed in high diversity of colour $(4.9-13.1 \%$ \& $3.1-17.6 \%$ of 
counts on PDA \& WA, respectively) from the three plant roots tested, where sugarcane had the best frequency and counts (100 $\& 70 \%$ of the samples and $13.1 \& 10.5 \%$ of the counts on PDA \& WA, respectively) as shown in tables, $(1 \& 2)$. White sterile fungi were the most dominant in three plant roots $(65,5,10 \%$ of the samples and 10.2, 0.7, $4.1 \%$ of the total fungi from sugarcane, jute and wheat, respectively) on PDA and prevalent in two plant roots on WA media (35 \& 10\% and $7 \& 2 \%$ from sugarcane and jute, respectively). In contrast, brown or blackish sterile fungi isolated from conifer roots were referred to by Melin $(1922,1923)$ as Mycelium radicis atrovirens Melin (MRA), but very little is known what comprises MRA, because the name has since been applied to any sterile, dark and septate fungus isolated from roots or soil (Jumpponen and Trappe, 1998). This group of fungi is prevalent in endophyte studies (Lacap et al., 2003; Shebany, 2008). recovered sterile mycelia from different organs of Altheae rosea, Calotropis procera and Nerium oleander with low counts (10.8\% of total fungi). Also, (Caruso et al., 2000). isolated sterile mycelium from woody and herbaceous tissues. Moreover, dark septate endophyte symbioses may indeed function physiologically as mycorrhizas in natural conditions, since some dark septate endophytes have been found to enhance host mineral nutrition and growth (Fernando and
Currah, 1996; Jumpponen et al., 1998). Mycorrhizal fungi enable their host plant to tolerate environmental extremes such as nitrogen and phosphorus deficiency, drought, low $\mathrm{pH}$, soil pollution, negative effects of some root pathogens etc. (Sylvia and Williams, 1992).

\section{Conclusion:}

The results obtained in this investigation in general accepted with the previous studies where, endophytic fungi are an ecological, polyphyletic group of highly diverse fungi, mostly belonging to ascomycetes and anamorphic fungi (Huang et al., 2001; Arnold, 2007). In addition to the positive role of endophytic fungi within the host depend on the nature of the association between endophytic fungi and their hosts are not considered as saprophytes (Valachová et $a l ., 2005)$. They are associated with living tissues, and may in some way contributed to the well being of the plant. That is, the plant thought to provide nutrients to the microbe, while the microbe may produce factors that protect the host plant from attack by animals, insects or microbes (Müller and Krauss, 2005; Lucero et al., 2006). Also, the dormance of endophytes in three nonleguminous compared with leguminous (ElMaghraby et al., 2013). may be related to presence of nitrogen fixing bacteria as endophytic bacteria. 


\begin{tabular}{|c|c|c|c|c|c|c|}
\hline \multirow{2}{*}{ Genera and species } & \multicolumn{2}{|c|}{ Sugarcane } & \multicolumn{2}{|c|}{ Jute } & \multicolumn{2}{|c|}{ Wheat } \\
\hline & TC & NCI & TC & $\begin{array}{c}\text { NC } \\
\text { I }\end{array}$ & TC & NCI \\
\hline Fusarium & 115 & 20 & 30 & 12 & 27 & 13 \\
\hline F. udum Butler & 43 & 13 & 12 & 8 & 3 & 2 \\
\hline $\begin{array}{l}\text { F. solani (Mart.) Appel \& Wollenweber emend. } \\
\text { Snyder \& Hansen }\end{array}$ & 20 & 9 & 8 & 4 & - & - \\
\hline F. anthophilum (A. Braun) Wollenweber & 16 & 7 & 1 & 1 & 6 & 3 \\
\hline F. subglutinans Wollenweber \& Reinking & 9 & 4 & 2 & 2 & 7 & 4 \\
\hline F. proliferatum (Matsushima) Nirenberg & 6 & 3 & 2 & 1 & 3 & 3 \\
\hline F. scirpi Lambotte \& Fautrey & 5 & 3 & - & - & - & - \\
\hline F. thapsinum Klittich, Leslie, Nelson \& Marasas & 4 & 3 & - & - & 2 & 2 \\
\hline F. verticillioides (Saccardo) Nirenberg & 7 & 2 & - & - & - & - \\
\hline F. oxysporum (Schlecht. emend.) Snyder \& & 3 & 2 & - & - & 4 & 2 \\
\hline Hansen & 1 & 1 & - & - & - & - \\
\hline F. nygamai Burgess \& Trimboli & 1 & 1 & - & - & - & - \\
\hline F. xylarioides Steyaert & - & - & 2 & 1 & - & - \\
\hline F. poae (Peck) Wollenweber & - & - & 2 & 1 & - & - \\
\hline F. semitectum Berkeley \& Ravenel & - & - & 1 & 1 & - & - \\
\hline F. equiseti (Corda) Saccardo & - & - & - & - & 2 & 1 \\
\hline F. decemcellulare Brick & 67 & 18 & 19 & 9 & 11 & 5 \\
\hline Aspergillus & 11 & 9 & - & - & 1 & 1 \\
\hline A. tubingensis (Schö-ber) Moss & 15 & 5 & - & - & - & - \\
\hline A. parasiticus Speare & 10 & 5 & 3 & 2 & 2 & 1 \\
\hline A. terreus var. aureus Thom \& Raper & 10 & 4 & - & - & - & - \\
\hline A. ochraceus Wilhelm & 8 & 4 & - & - & - & - \\
\hline A. flavus var. columnaris Fennell \& Raper & 7 & 4 & 6 & 4 & 2 & 1 \\
\hline A. flavus link & 2 & 2 & 3 & 2 & - & - \\
\hline A. ficuum (Reich.) Hennings & - & - & - & - & 2 & 2 \\
\hline A. ustus (Bain.) Thom \& Church & 2 & 2 & - & - & 1 & 1 \\
\hline A. phoenicis (Cda.) Thom & 1 & 1 & - & - & - & - \\
\hline A. flavo-furcatis Batista \& Maia & 1 & 1 & 4 & 3 & 1 & 1 \\
\hline A. terreus Thom & - & - & 1 & 1 & - & - \\
\hline A. fumigatus Fresenius & - & - & 1 & 1 & - & - \\
\hline A. subsessilis Thom \& Raper & - & - & 1 & 1 & - & - \\
\hline A. terricola Marchal & - & - & - & - & 1 & 1 \\
\hline A. puniceus Kwon \& Fennell & - & - & - & - & 1 & 1 \\
\hline A. speluneus Thom \& Raper & 22 & 8 & - & - & - & - \\
\hline $\begin{array}{l}\text { Trichoderma ghanense Doi, Y. Abe \& J. } \\
\quad \text { Sugiyama } \\
\text { Emericella nidulans (Eidam) Wint }\end{array}$ & - & - & 2 & 2 & - & - \\
\hline
\end{tabular}

Table (1): Total counts (TC, calculated per 400 root segments) and number of case of isolation (NCI, out of 20 samples) of fungal genera and species isolated from sugarcane, jute and wheat roots on potato dextrose agar (PDA) at $28 \pm 2^{\circ} \mathrm{C}$. 


\begin{tabular}{|c|c|c|c|c|c|c|}
\hline \multirow{2}{*}{ Genera and species } & \multicolumn{2}{|c|}{ Sugarcane } & \multicolumn{2}{|c|}{ Jute } & \multicolumn{2}{|c|}{ Wheat } \\
\hline & TC & NCI & TC & NCI & TC & NCI \\
\hline Hypocrea vinosa Bissett & 18 & 8 & - & - & - & - \\
\hline Penicillium & 13 & 6 & 1 & 1 & 2 & 2 \\
\hline P. corylophilum Dierckx & 4 & 3 & - & - & - & - \\
\hline P. ducluxi Delacroix & 3 & 1 & - & - & 1 & 1 \\
\hline P. islandicum Sopp & 2 & 1 & - & - & - & - \\
\hline P. rubrum Stoll & 2 & 1 & - & - & - & - \\
\hline P. funiculosum Thom & 1 & 1 & 1 & 1 & - & - \\
\hline P. pulvillorum Turfitt & 1 & 1 & - & - & - & - \\
\hline P. resticulosum Birkinshaw, Raistrick and Smith & - & - & - & - & 1 & 1 \\
\hline Drechslera & 7 & 4 & 14 & 8 & 10 & 5 \\
\hline D. biseptata (Sacc. \& Roum.) Richardson \& Fraser & 7 & 4 & 2 & 2 & 5 & 3 \\
\hline D. halodes (Drechsler) Subram. \& Jain & - & - & 4 & 4 & - & - \\
\hline $\begin{array}{l}\text { D. hawaiiensis (Bugnicourt) Subram. \& Jain ex M. B. } \\
\text { Ellis; Subram. \& Jain }\end{array}$ & - & - & 2 & 2 & - & - \\
\hline D. holmii (Luttrell) Subram. \& Jain & - & - & 4 & 1 & - & - \\
\hline D. miyakei (Nisikado) Subram. \& Jain & - & - & 1 & 1 & - & - \\
\hline D. rostrata (Drechsler) Richardson \& Fraser & - & - & 1 & 1 & - & - \\
\hline D. bicolor Paul \& Parbery & - & - & - & - & 4 & 2 \\
\hline D. carbonus Nelson & - & - & - & - & 1 & 1 \\
\hline Cylindrocarpon & 5 & 4 & 25 & 6 & 1 & 1 \\
\hline C. didymium (Hartung) Wollenweber & 5 & 4 & - & - & - & - \\
\hline C. radicicola Wollenweber & - & - & 25 & 6 & - & - \\
\hline C. candidum var. majus Wollenweber & - & - & - & - & 1 & 1 \\
\hline Stachybotrys bisbyi (Bisby) Corda & 4 & 2 & - & - & - & - \\
\hline Cladosporium & 3 & 2 & - & - & - & - \\
\hline C. herbarum (Pers.) Link ex S. F. Gray & 2 & 1 & - & - & - & - \\
\hline C. cladosporoides (Fresen.) de Vries & 1 & 1 & - & - & - & - \\
\hline Paecilomyces & 3 & 2 & - & - & 1 & 1 \\
\hline P. fumosoroseus Bainier & 3 & 2 & - & - & - & - \\
\hline P. terricola Bainier & - & - & - & - & 1 & 1 \\
\hline Botryotrichum atrogriseum van Beyma & - & - & 5 & 2 & - & - \\
\hline Curvularia & 2 & 2 & 11 & 6 & 5 & 3 \\
\hline C. clavata Jain & 1 & 1 & - & - & 1 & 1 \\
\hline C. lunata (Wakker) Boedijn & 1 & 1 & 6 & 4 & - & - \\
\hline C. oryzae Bugnicourt & - & - & 3 & 2 & - & - \\
\hline C. ovoidea (Hiroe \& Watan.) Muntañola & - & - & 2 & 1 & - & - \\
\hline C. pallescens Boedijn & - & - & - & - & 3 & 1 \\
\hline C. brachyspora Boedijn & - & - & - & - & 1 & 1 \\
\hline
\end{tabular}

Table (1): continued. 


\begin{tabular}{|c|c|c|c|c|c|c|}
\hline \multirow{2}{*}{ Genera and species } & \multicolumn{2}{|c|}{ Sugarcane } & \multicolumn{2}{|c|}{ Jute } & \multicolumn{2}{|c|}{ Wheat } \\
\hline & $\mathbf{T C}$ & NCI & $\mathbf{T C}$ & NCI & $\mathbf{T C}$ & NCI \\
\hline Macrophomina phaseoli (Maublanc) Ashby & 4 & 1 & 10 & 4 & - & - \\
\hline Gilmaniella humicola Barron & 2 & 1 & - & - & - & - \\
\hline Humicola & 2 & 1 & 2 & 1 & 2 & 2 \\
\hline H. grisea Traaen & 2 & 1 & - & - & 1 & 1 \\
\hline H. fuscoatra Traaen & - & - & 2 & 1 & 1 & 1 \\
\hline Alternaria & 1 & 1 & 11 & 4 & 2 & 1 \\
\hline A. tenuissima (Kunze: ex Pers.) Wilshire & 1 & 1 & 3 & 3 & - & - \\
\hline A. alternata (Fr.) Keissler & - & - & 7 & 3 & 2 & 1 \\
\hline A. longipes (Ellis \& Everh.) Mason & - & - & 1 & 1 & - & - \\
\hline Ascotricha xylina Lentz \& Hawksworth & - & - & - & - & 1 & 1 \\
\hline Cephalosporium coremioides Raillo & 1 & 1 & - & - & - & - \\
\hline Histoplasma capsulatum Darling & - & - & - & - & 1 & 1 \\
\hline Memnoniella subsimplex (Cooke) Deighton & - & - & - & - & 1 & 1 \\
\hline Mucor hiemalis Wehmer & 1 & 1 & - & - & - & - \\
\hline Myrothecium roridum Tode ex Fries & - & - & 2 & 1 & - & - \\
\hline Nigrospora panici Zimm & 1 & 1 & - & - & - & - \\
\hline Scopulariopsis & 1 & 1 & 2 & 1 & 1 & 1 \\
\hline S. humicola (Sacc.) Bainier & 1 & 1 & - & - & - & - \\
\hline S. brevicaulis (Sacc.) Bainier & - & - & 2 & 1 & - & - \\
\hline S. brumptii Salvanet-Duval & - & - & - & - & 1 & 1 \\
\hline Scytalidium lignicola Pesante & - & - & 1 & 1 & - & - \\
\hline Spicaria violacea Abbott & - & - & 1 & 1 & - & - \\
\hline Torula herbarum (Pers.) Link ex Fries & - & - & - & - & 1 & 1 \\
\hline Trichothecium roseum (Pers.) Link ex Gray & 1 & 1 & - & - & - & - \\
\hline Sterile mycelium (white) & 32 & 13 & 1 & 1 & 3 & 2 \\
\hline Sterile mycelium (gray) & 2 & 2 & 2 & 2 & 2 & 2 \\
\hline Sterile mycelium (pale brown pink) & 2 & 2 & - & - & - & - \\
\hline Sterile mycelium (gray green) & 2 & 1 & - & - & - & - \\
\hline Sterile mycelium (olive-gray) & - & - & - & - & 2 & 2 \\
\hline Sterile mycelium (white yellow) & 2 & 1 & - & - & - & - \\
\hline Sterile mycelium (white orange) & 1 & 1 & - & - & - & - \\
\hline Sterile mycelium (drip white) & - & - & - & - & 1 & 1 \\
\hline Sterile mycelium (rose-white) & - & - & 2 & 1 & - & - \\
\hline Sterile mycelium (violet-white) & - & - & 1 & 1 & - & - \\
\hline Sterile mycelium (versicolor) & - & - & 1 & 1 & - & - \\
\hline Total count & 314 & & 143 & & 74 & \\
\hline NO. of genera & 20 & & 15 & & 14 & \\
\hline NO. of species+ varieties & $44+2$ & & $36+1$ & & $31+2$ & \\
\hline
\end{tabular}

Table (1): continued. 


\begin{tabular}{|c|c|c|c|c|c|c|}
\hline \multirow{2}{*}{ Genera and species } & \multicolumn{2}{|c|}{ Sugarcane } & \multicolumn{2}{|c|}{ Jute } & \multicolumn{2}{|c|}{ Wheat } \\
\hline & $\mathbf{T C}$ & NCI & TC & NCI & $\mathbf{T C}$ & NCI \\
\hline Fusarium & 102 & 19 & 34 & 11 & 25 & 8 \\
\hline $\begin{array}{l}\text { F. solani (Mart.) Appel \& Wollenweber emend. } \\
\text { Snyder \& Hansen }\end{array}$ & 25 & 10 & 3 & 3 & - & - \\
\hline F. udum Butler & 31 & 6 & 5 & 2 & 2 & 1 \\
\hline F. thapsinum Klittich, Leslie, Nelson \& Marasas & 19 & 5 & - & - & 16 & 5 \\
\hline F. scirpi Lambotte \& Fautrey & 8 & 4 & - & - & - & - \\
\hline F. chlamydosporum Wollenweber \& Reinking & 14 & 3 & - & - & - & - \\
\hline F. anthophilum (A. Braun) Wollenweber & 3 & 1 & - & - & 6 & 2 \\
\hline F. nygamai Burgess \& Trimboli & 2 & 1 & - & - & - & - \\
\hline F. semitectum Berkeley \& Ravenel & - & - & 16 & 4 & - & - \\
\hline $\begin{array}{l}\text { F. oxysporum (Schlecht. emend.) Snyder \& } \\
\text { Hansen }\end{array}$ & - & - & 7 & 4 & - & - \\
\hline F. equiseti (Corda) Saccardo & - & - & 1 & 1 & - & - \\
\hline F. proliferatum (Matsushima) Nirenberg & - & - & 1 & 1 & - & - \\
\hline F. verticillioides (Saccardo) Nirenberg & - & - & 1 & 1 & - & - \\
\hline F. subglutinans Wollenweber \& Reinking & - & - & - & - & 1 & 1 \\
\hline Drechslera & 58 & 18 & 3 & 2 & 13 & 8 \\
\hline $\begin{array}{l}\text { D. biseptata (Sacc. \& Roum.) Richardson \& } \\
\text { Fraser }\end{array}$ & 34 & 13 & - & - & - & - \\
\hline D. bicolor Paul \& Parbery & 19 & 7 & - & - & 1 & 1 \\
\hline D. spicifer Nelson & 3 & 1 & - & - & 7 & 3 \\
\hline D. halodes (Drechsler) Subram. \& Jain & 2 & 1 & 2 & 1 & 2 & 2 \\
\hline D. miyakei (Nisikado) Subram. \& Jain & - & - & 1 & 1 & - & - \\
\hline $\begin{array}{l}\text { D. dematioidea (Bubák \& Wróblewski) Subram. } \\
\text { \& Jain }\end{array}$ & - & - & - & - & 3 & 2 \\
\hline Hypocrea vinosa Bissett & 15 & 7 & - & - & - & - \\
\hline Aspergillus & 12 & 6 & 19 & 7 & 4 & 3 \\
\hline A. tubingensis (Schö-ber) Moss & 4 & 3 & - & - & 2 & 2 \\
\hline A. terreus var. aureus Thom \& Raper & 7 & 2 & 1 & 1 & - & - \\
\hline A. ochraceus Wilhelm & 1 & 1 & - & - & - & - \\
\hline A. terreus Thom & - & - & 18 & 7 & - & - \\
\hline A. ficuum (Reich.) Hennings & - & - & - & - & 2 & 1 \\
\hline Cylindrocarpon & 11 & 5 & 13 & 5 & 6 & 4 \\
\hline C. didymium (Hartung) Wollenweber & 11 & 5 & 4 & 2 & 6 & 4 \\
\hline C. radicicola Wollenweber & - & - & 9 & 5 & - & - \\
\hline Cephalosporium coremioides Raillo & 20 & 4 & - & - & - & - \\
\hline Stachybotrys & 9 & 2 & 1 & 1 & 1 & 1 \\
\hline S. bisbyi (Bisby) Corda & 9 & 2 & - & - & - & - \\
\hline S. atra Corda & - & - & 1 & 1 & 1 & 1 \\
\hline
\end{tabular}

Table (2): Total counts (TC, calculated per 400 root segments) and number of case of isolation (NCI, out of 20 samples) of fungal genera and species isolated from sugarcane, jute and wheat roots on water agar (WA) at $28 \pm 2^{\circ} \mathrm{C}$. 


\begin{tabular}{|c|c|c|c|c|c|c|}
\hline \multirow{2}{*}{ Genera and species } & \multicolumn{2}{|c|}{ Sugarcane } & \multicolumn{2}{|c|}{ Jute } & \multicolumn{2}{|c|}{ Wheat } \\
\hline & TC & NCI & TC & NCI & TC & NCI \\
\hline Alternaria alternate (Fr.) Keissler & 4 & 2 & - & - & 1 & 1 \\
\hline Scopulariopsis & 2 & 2 & 3 & 3 & 7 & 3 \\
\hline S. brumptii Salvanet-Duval & 2 & 2 & - & - & 7 & 3 \\
\hline S. brevicaulis (Sacc.) Bainier & - & - & 3 & 3 & - & - \\
\hline Penicillium & 3 & 1 & 1 & 1 & 11 & 5 \\
\hline P. ducluxi Delacroix & 3 & 1 & - & - & - & - \\
\hline P. corylophilum Dierckx & - & - & - & - & 5 & 2 \\
\hline P. funiculosum Thom & - & - & - & - & 4 & 2 \\
\hline P. islandicum Sopp & - & - & - & - & 1 & 1 \\
\hline P. rubrum Stoll & - & - & - & - & 1 & 1 \\
\hline P. piscarium Westling & - & - & 1 & 1 & - & - \\
\hline Cladosporium & - & - & - & - & 6 & 3 \\
\hline C. cladosporioides (Fresen.) de Vries & - & - & - & - & 3 & 3 \\
\hline C. herbarum (Pers.) Link ex S. F. Gray & - & - & - & - & 3 & 1 \\
\hline Curvularia & 1 & 1 & 10 & 6 & 1 & 1 \\
\hline C. intermedia Boedijn & 1 & 1 & - & - & - & - \\
\hline C. lunata (Wakker) Boedijn & - & - & 10 & 6 & - & - \\
\hline C. ovoidea (Hiroe \& Watan.) Muntañola & - & - & - & - & 1 & 1 \\
\hline Nigrospora panici Zimm & 1 & 1 & - & - & - & - \\
\hline Humicola grisea Traaen & - & - & 2 & 2 & - & - \\
\hline Macrophomina phaseoli (Maublanc) Ashby & - & - & 5 & 2 & - & - \\
\hline Epicoccum purpurascens Ehrenberg & - & - & 1 & 1 & - & - \\
\hline Sporotrichum pruinosum Gilman \& Abbott & - & - & 1 & 1 & - & - \\
\hline Sterile mycelium (white) & 19 & 7 & 2 & 2 & - & - \\
\hline Sterile mycelium (olive-brown) & 6 & 4 & - & - & - & - \\
\hline Sterile mycelium (white gray) & 2 & 2 & - & - & 2 & 1 \\
\hline Sterile mycelium (white yellow) & 1 & 1 & - & - & - & - \\
\hline Sterile mycelium (rose-white) & - & - & 1 & 1 & - & - \\
\hline Sterile mycelium (gray) & - & - & - & - & 6 & 5 \\
\hline Sterile mycelium (white olive) & - & - & - & - & 8 & 3 \\
\hline Total count & 266 & & 96 & & 91 & \\
\hline NO. of genera & 12 & & 12 & & 10 & \\
\hline NO. of species+ varieties & $22+1$ & & $20+1$ & & $21+0$ & \\
\hline
\end{tabular}

Table (2): continued. 


\begin{tabular}{|c|c|c|c|}
\hline Phylum & Order & PDA & WA \\
\hline Anamorphic fungi & $\begin{array}{c}\text { Hypocreales } \\
\text { Pleosporales } \\
\text { Sordariales } \\
\text { Microascales } \\
\text { Capnodiales } \\
\text { Botryosphaeriales } \\
\text { Trichosphaeriales } \\
\text { Xylariales } \\
\text { Onygenales } \\
\text { Helotiales } \\
\text { Saccharomycetales } \\
\text { Stereales } \\
\text { Eurotiales } \\
\text { Mucorales }\end{array}$ & $\begin{array}{l}26 \text { species under } 10 \text { genera } \\
17 \text { species under } 3 \text { genera } \\
3 \text { species under } 2 \text { genera } \\
3 \text { species under } 1 \text { genus } \\
2 \text { species under } 1 \text { genus } \\
1 \text { species under } 1 \text { genus } \\
1 \text { species under } 1 \text { genus } \\
1 \text { species under } 1 \text { genus } \\
1 \text { species under } 1 \text { genus } \\
1 \text { species under } 1 \text { genus } \\
1 \text { species under } 1 \text { genus } \\
- \\
26 \text { species under } 4 \text { genera } \\
1 \text { species under } 1 \text { genus }\end{array}$ & $\begin{array}{c}19 \text { species under } 5 \text { genera } \\
11 \text { species under } 4 \text { genera } \\
1 \text { species under } 1 \text { genus } \\
2 \text { species under } 1 \text { genus } \\
2 \text { species under } 1 \text { genus } \\
1 \text { species under } 1 \text { genus } \\
1 \text { species under } 1 \text { genus } \\
- \\
- \\
- \\
- \\
11 \text { species under } 1 \text { genus } \\
\text { species under } 2 \text { genera }\end{array}$ \\
\hline 3 & 14 & & \\
\hline
\end{tabular}

Table (3): Number of fungal genera, species, order and phylum of endophytic fungi isolated from the three non-leguminous plants and their order and phylum on PDA and WA at $28 \pm 2{ }^{\circ} \mathrm{C}$.

\section{Reference}

Abd-Elaah, A.G. and Soliman, A.S. (2005): Effect of fluconazole on mycelia growth and protein profiles of some fungal species isolated from molasses. Assiut Univ. J. Bot. 34: 131-145.

Arnold, A.E. (2007): Understanding the diversity of foliar endophytic fungi: progress, challen-ges, and frontiers. Fungal Biology Re-views 21: 51-66.

Basu, A.; Ghosh, M.; Meyer, R.; Powell, W.; Basak, S.L. and Sen, S.K. (2004): Analysis of genetic diversity in cultivated jute determined by means of SSR markers and AFLP profiling. Crop Science. 44: 678-685.

BBS. (2004): Statistical pocket book of Bangladesh statistics division, Bangladesh Bureau of Statistics, Ministry of Planning, the People's Republic of Bangladesh.

Bhoja, Basnet, R.; Ali, M.B.; Ibrahim, A.M.H.; Payne, T. and Mosaad, M.G. (2011): Evaluation of genetic bases and diversity of Egyptian wheat cultivars released during the last 50 years using coefficient of parentage. Int. J. Agric. Biol. 6: 31-47.
Bussaban, B., Lumyong S., Lumyong, P., McKenzie, E.H.C. and Hyde, K.D. (2001): Endophytic fungi from Amomum siamense. Can. J. Microbiol. 47: 943-948.

Cappellano, A.; de Quartre, B.; Valla, G. and Moiroudo, A. (1987): Root nodule formation by Penicillium sp. on Alnus glutinosa and Alnus incana. Plant Soil, 104: 45-51.

Caruso, M.; Colombo, A.L.; Fedeli, L.; Pavesi, A.; Quaroni, S.; Saracchi, M. and Ventrella, G. (2000): Isolation of endophytic fungi and actinomycetes taxane producers. Ann. Microbiol. 50: 313.

Clay, K. (1991): Fungal endophytes, grasses, and herbivores. in: Microbial Mediation of Plant-herbivore Interaction. P. Barbosa, V.A., Krischik and C.G., Jones, eds. John Wiley and Sons, Inc., New York. 199252.

Ellis, M.B. (1971): Dematiaceous Hyphomycetes, Commonwealth Mycol. Inst., Kew, Surrey, England. pp. 608.

El-Maghraby, O.M.O.; Soltan, S.M.; Rehab, M. Mohammed and Maha, M. Mohammed (2013): Endophytic fungi of three leguminous plant roots in 
Egypt. J. Bas. Appl. Mycol. Egypt. 4: 59-68.

FAO

(2013):

http://www.fao.org/news/story/en/item /179967/

Fatma, F. Abdel-Motaal; Nassar, M.S.M.; Soad, A. El-zayat; El-Sayed, M.A. and Shin-Ichi Ito (2010): Antifungal activity of endophytic fungi isolated from Egyptian henbane (Hyoscyamus muticus L.). Pak. J. Bot. 42: 28832894.

Fávaro, L.C.L.; Melo, F.L.; Aguilar-Vildoso, C.I.; Araújo, W.L. (2011): Polyphasic analysis of intraspecific diversity in Epicoccum nigrum warrants reclassification into separate species. PLoS One 6: e14828.

Fernando, A.A. and Currah, R.S. (1996): A comparative study of the effects of the root endophytes Leptodontidium orchidicola and Phialocephala fortinii (Fungi Imperfecti) on the growth of some subalpine plants in culture. Can. J. Bot. 74: 1071-1078.

Fisher, P.J.; Petrini, O. and Webster, J. (1991): Aquatic hyphomycetes and other fungi in leaving aquatic and terrestrial roots of Alnus glutionsa. Mycol. Res. 95: 543-547.

Ganley, R.J. and Newcombe, G. (2006): Fungal endophytes in seeds and needles of Pinus monticola. Mycol. Res. 110: 318-327.

Götz, M.; Nirenberg, H.; Krause, S.; Wolters, H.; Draeger, S.; Buchner, A.; Lottmann, J.; Berg, G. and Smalla, K. (2006): Fungal endophytes in potato roots studied by traditional isolation and cultivation-independent DNAbased methods. FEMS Microbiol. Ecol. 58: 404-413.

Hallmann, J.; Berg, G. and Schulz, B. (2007): Isolation Procedures for Endophytic Microorganisms. Springer, New York, Berlin Heidelberg, 299319.

Hirsch, G.U. and Braun, U. (1992): Communities of parasitic microfungi. In hand book of Vegetation Science (ed. W. Winterhoff) Kluwer, Dordrecht, 19: 225-250.

Hoff, J.A.; Klopfenstein, N.B.; Tohn, J.R.; McDonald, G.I.; Zambina, P.J.; Rogers, J.D.; Peever, T.L. and Carris, L.M. (2004): Roles of woody root-associated fungi in forest ecosystem processes: Recent Advances in Fungal Identification.USD Forest Service RMRS-RP.47.

Huang, Y.; Wang, J.; Li, G.; Zheng, Z. and Su, W. (2001): Antitumor and antifungal activities in endophytic fungi isolated from pharma-ceutical plants Taxus mairei, Cephalataxus fortunei and Torreya grandis. FEMS Immun. Med. Microb. 31: 163-167.

Ibrahim, T.A. and Fagbohun, E.D. (2011): Physicochemical proprieties and in vitro anti-bacterial activity of Corchorus olitorius Linn. Seed oil. Life Sci. leaflets. 15: 499-505.

Jangpromma, N.; Kitthaisong, S.; Lomthaisong, K.; Daduang, S.; Jaisil, P. and Thammasirirak, S. (2010): A proteomics analysis of drought stressresponsive proteins as biomarker for drought-tolerant sugarcane cultivars. Am. J. Agric. Biol. Sci. 6: 89-102.

Jumpponen, A. and Trappe, J.M. (1998): Dark septate endophytes: a review of facultative biotrophic root-colonizing fungi. New Phytol. 140: 295-310.

Jumpponen, A.; Mattson, K.G. and Trappe, J.M. (1998): Mycorrhizal functioning of Phialocephala fortinii with Pinus contorta on glacier forefront soil: Interactions with soil nitrogen and organic matter. Mykorrhiza 7: 261265.

Keka, S.I.; Shamsuzzaman, M.; Pahloan, M.U.; Pervin, S.; Rahman, M.M. and Khan, H. (2008): Identifying simple sequence repeat (SSR) marker linked to mite tolerance in jute species. Bangladesh J. Bot. 37: 161-171.

Krings, M.; Taylor, T.N.; Hass, H.; Kerp, H.; Dotzler, N. and Hermsen, E.J. (2007): Fungal endophytes in a 400-millionyr-old land plants: infection pathways, spatial distribution, and host response. New Phytologist 174: 648-657.

Lacap, D.C.; Hyde, K.D. and Liew, E.C.Y. (2003): An evaluation of the fungal "morphotype" concepts based on ribosomal DNA sequence. Fungal Diversity 12: 53-66.

Larran, S., Rollan, C. Angeles, H.B., Alippi, H.E. and Urrutia, M.I. (2002): 
Endophytic fungi in healthy soyabean leave investigation agraria. Prod. Prot. Veget. 17: 173-178.

Leslie, J.F. and Summerell, B.A. (2006): The Fusarium Laboratory Manual. A Recent History. Mycotoxin Research 22: 73-74.

Lodge, D.J.; Fisher, P.J. and Sutton, B.C. (1996): Endophytic fungi of Manilkara bidentata leaves in Puerto, Rico. Mycol.88 (5): 733-738.

Lucero, M.E.; Barrow, J.R.; Osuna, P. and Reyes, I. (2006): Plant-fungal interactions in arid and semi-arid ecosystem: Largescale impacts from microscale processes. J. Arid Environ. 65: 276-284.

Mahmood, A.; Ishfaq, M.; Iqbal, J. and Nazir, M.S. (2007): Agronomic performance and juice quality of autumn planted sugarcane (Saccharum officinarum L.) as affected by flat, ditch and pit planting under different spatial arrangements. Int. J. Agric. Biol. 9: 167-169.

Melin, E. (1922): On the mycorrhizas of Pinus sylvestris L. and Picea abies Karst. A preliminary note. J. Ecol. 9: 254-257.

Melin, E. (1923): Experimentelle untersuchungen über die konstitution und ökologie den mykorrhizen von Pinus silvestris und Picea abies. Mykologische Untersuchungen und Berichte Von R Falck 2: 73-331.

Mohammed, M. Maha (2010): Studies on endophytic microorganisms of some medicinal plants. M. Sc. Thesis, Sohag Univ., Sohag, Egypt.

Müller, C.B. and Krauss, J. (2005): Symbiosis between grasses and asexual fungal endophytes. Current Opin. In Plant Biol. 8: 450-456.

Nath, A.; Raghunatha, P. and Joshi, S.R. (2012): Diversity and Biological Activities of Endophytic Fungi of Emblica officinalis, An Ethnomedicinal Plant of India. Res. Art. Mycobiol. 40: 8-13.

Ndlovu, J. and Afolayan, A.J. (2008): Nutritional analysis of the South African wild vegetable Corchorus olitorius L. Asian J. of Plant Sci. 7: 615-618.

Pitt, J.I. (1979): The Genus Penicillium And Its Teleomorphic States Eupenicillium and
Talaromyces. Commonwealth Scientific and Industrial Research Organization, Division of food Research, North Ryde, N. S. W. Australia, Academic Press, INC. Ltd., London. pp. 634.

Raper, K.B. and Fennell. D.J. (1965): The Genus Aspergillus, Williams and Wilkins, Baltimore, USA. pp. 686.

Rubini, M.R.; Silva-Ribeiro, R.T.; Pomella, A.W.V.; Maki, C.S.; Araújo, W.L.; Santos, D.R. and Azevedo, J.L. (2005): Diversity of endophytic fungal community of cacao (Theobroma cacao. L) and biological control of Crinipellis perniciosa, causal agent of Witches Broom Disease. Int. J. Biol. Sci. 1: 24-33.

Samra, I.; Piliz, S. and Ferdag, C. (2007): Antibacterial and antifungal activity of Corchorus olitorius L. (Molekhia extracts) Int. J. Nat. Engin. Sci. 1: 3961.

Shebany, Y.M. (2008): Endophytic fungi of three medicinal plants and effect of plant extracts against pathogenic bacteria and fungi. $\mathrm{Ph}$. D. Thesis, South valley Univ., Qena, Egypt.

Singh, R.K.; Mishra, S.K.; Singh, S.P.; Mishra, N. and Sharma, M.L. (2010): Evaluation of microsatellite markers for genetic diversity analysis among sugarcane species and commercial hybrids. Aust. J. Crop Sci. 4: 115-124.

Souza, D.R.D.; Stingel, E.; Almeida, L.C.D.; Munhae C.B. and Mayhe-Nunes, A.J. (2010): A diversity in a sugarcane culture without the use of straw burning in southeast, San Paulo, Brazil. Amer. J. Agric. Biol. Sci. 5: 183-188.

Strobel, G.A. and Daisy, B. (2003): Bioprospecting for microbial endophytes and their natural products. Microbiol. Mol. Biol. Rev. 67: 491502.

Stuart, R.M.; Romão, A.S.; PizziraniKleiner, A.A.; Azevedo, J.L.; Araújo, W.L. (2010): Culturable endophytic filamentous fungi from leaves of transgenic imidazolinone-tolerant sugarcane and its non-transgenic isolines. Arch. Microbiol. 192: 307313.

Sylvia, D.M. and Williams, S.E. (1992): Vesicular-arbuscular mycorrhizae and 
$\begin{array}{lcl}\text { environmental } & \text { stresses. In: } \\ \text { Bethlenfalvay G. J. \& Linderman R.G. }\end{array}$ (Eds.), Mycorrhizae in sustainable agriculture, ASA No 54, Madison, Wisconsin, USA. 101-123.

Tian, X.L.; Cao, L.X.; Tan, H.M.; Zeng, Q.G.; Jia, Y.Y.; Han, W.Q. and Zhou, S.N. (2004): Study on the communities of endophytic fungi and endophytic actinomycetes from rice and their antipathogenic activities in vitro. World $\mathrm{J}$. Microbiol. Biotechnol. 20: 303-309.

Valachová, M.; Jedinak, A. and Maliar, T. (2005): Antiprotease activity of endophytic microorganisms isolated from medical plants. Nova Biotech. 65-72.

Vega, F.E.; Posada, F.; Aime, M.C.; PavaRipoll, M.; Infante, F. and Rehner, S.A. (2008): Entomopathogenic fungal endophytes. Biological Control, 46: 7282.
Wang, B.; Priest, M.J.; Davidson, A.; Brubaker, C.L.; Woods, M.J. and Burdon, J.J. (2007): Fungal endophytes of native Gossypium species in Australia. Mycol. Res. 3: 347-354.

Weber, R.W.S.; Kappe, R.; Paululat, T.; Mosker, E. and Anke, H. (2007): Anti-Candida metabolites from endophytic fungi. Phytochem. 68: 886-892.

Wijeratne, E.M.K.; Paranagama, P.A. and Leslie Gunatilaka, A.A. (2006): Five new isocoumarins from Sonoran desert plantassociated fungal strains Paraphaeosphaeria quadriseptata and Chaetomium chiversii. Tetrahedron. 62: 8439-8446.

Zaki, Nabila, M.; Hassanein, M.S. and Gamal El-Din, Karima, M. (2007): Growth and yield of some wheat cultivars irrigated with saline water in newly cultivated land as affected by biofertilization. J. Appl. Sci. Res. 3: 1121-1126.

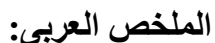

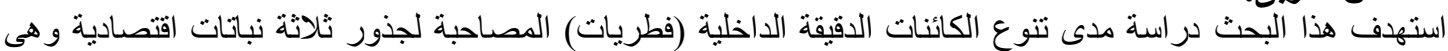

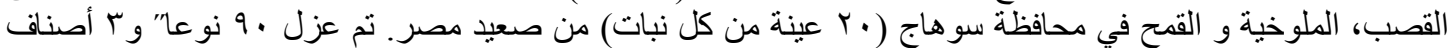

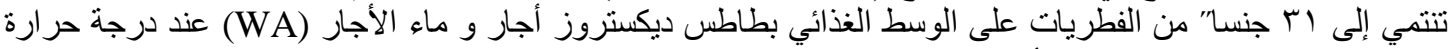

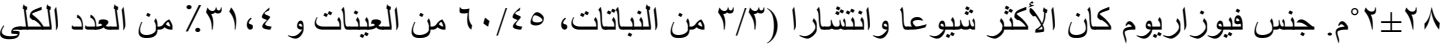

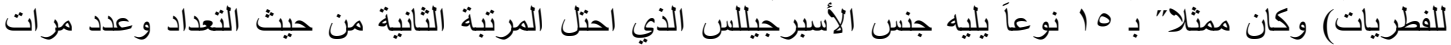

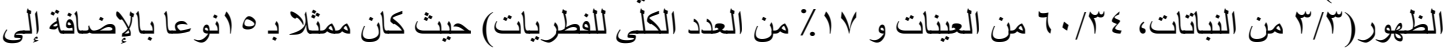

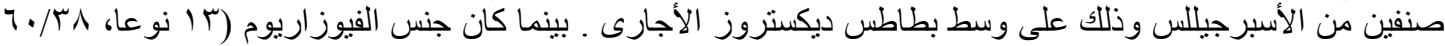

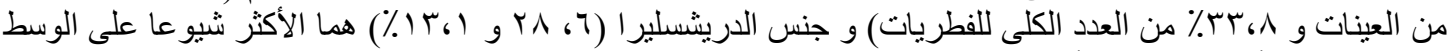

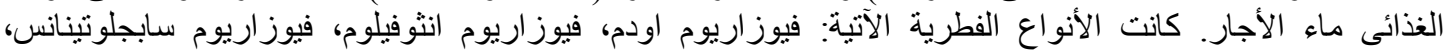

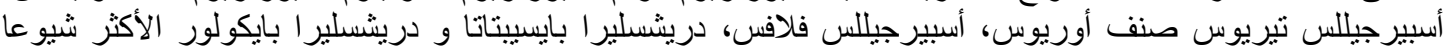

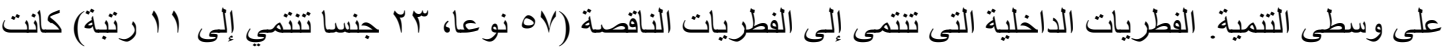

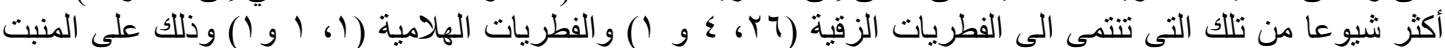

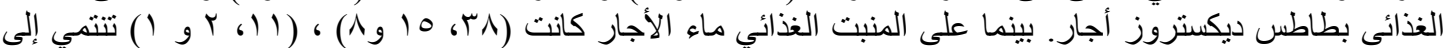

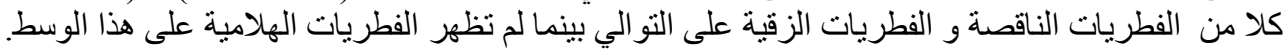

